\title{
SOVIETMEČIO MODERNIZMO ARCHITEKTŪROS PRARADIMAI LIETUVOJE
}

\author{
Julija Kšivickaitė \\ Architektūros pagrindu ir teorijos katedra, \\ Vilniaus Gedimino technikos universitetas, Pylimo g. 26/Trakug. 1, LT-01132 Vilnius, Lietuva \\ El.paštas julija.ksivickaite@gmail.com \\ Iteikta 20080526
}

\begin{abstract}
Santrauka. Nagrinejjamas sovietmečio architektūros palikimas Lietuvoje ir keliama hipotezè, kad Lietuvoje yra modernizmo stiliaus bruožų turinčių pastatų, kurie nevertinami nyksta. Darbe aptariami XX a. architektūros raidos ypatumai, analizuojamas sudètingas ir nevienareikšmis požiūris ị Lietuvos modernizmo architektūros palikimą ir susidariusios situacijos priežastys. Lyginant buvusią ir dabartinę Lietuvos modernizmo architektūros pavyzdžių būklę, išskiriamos ir sisteminamos didžiausios tokių pastatų transformacijos, pristatomi būdingi pastatai ir jų bruožai. Prieinama prie išvados, kad Lietuvos XX amžiaus architektūros pavyzdžiai sparčiai nyksta, todèl juos būtina fiksuoti ir saugoti.

Reikšminiai žodžiai: sovietmetis, modernizmas, architektūros palikimas, transformacijos, praradimai.
\end{abstract}

\section{Ivadas}

Architektūra, apimdama didelę dalị gyvenamosios ir socialinès aplinkos, lemia vietos identiteto suvokimą, joje atsispindi laikotarpio socialiniai, ekonominiai ir ideologiniai reiškiniai. XX amžiuje, atsiskyrus architekto ir inžinieriaus specialybèms, lengvejjant gamybos bei kūrybos procesams, architektūra tapo socialinio gyvenimo ir minties raidos indikatoriumi. Europos moderniosios architektūros judejimai ir kryptys iliustruoja laikotarpio sociopolitinę, ekonominę situaciją ir parodo kūrybini šių laikų architektūros potencialą, todèl, norint atrasti savo vietą bendrame architektūriniame kontekste, būtina suvokti ir vertinti visų istorijos sluoksnių palikimą. XX amžiaus architektūra neturetų būti išimtis.

Didžioji XX a. Lietuvos architektūros dalis buvo sukurta sovietmečiu, tai lemia nevienareikšmi požiūrị i jos palikimą. Dažniausiai tokia architektūra neturi jokio apsaugos statuso ir greitai nyksta iš miesto architektūrinio žemèlapio, o kartu ir iš istorijos. „Peržengus XXI a. slenkstị, antroji praejjusio amžiaus pusè nenumaldomai virsta istorine realybe. Miestai vis labiau keičiasi, pastatai rekonstruojami ar griaunami, miestovaizdis igyja naujo amžiaus kokybę <...>. Akivaizdu, kad tokioje situacijoje būtina fiksuoti dar nesenas, atmintyje gyvas, bet itin greitai istorinemis tampančias miesto formas", - rašo Vaidas Petrulis (2005: 3).
Profesionaliosios literatūros Lietuvos modernizmo architektūros tema nèra daug. Nagrinèjamos atskiros temos: industrinè modernizmo architektūra (Drèmaitè 2004), etiniai sovietmečio architektūros vertinimai ir nacionalinio savitumo klausimai (Petrulis 2005, 2006, 2007), XX amžiaus architektūros kryptys ir kiti kontekstai (R. Buivydas 2001, 2003, 2004), tačiau nèra $\mathrm{XX}$ amžiaus architektūros palikimo ir dabartinès būklès analizès. Daugelis modernizmo architektūrą aprašančių straipsnių paskelbti sovietmečio periodinèje spaudoje, todèl yra ganètinai ideologizuoti ir šių laikų kontekste skaitomi kitaip. Todèl šiame straipsnyje analizuojamas $\mathrm{XX}$ amžiaus antrosios pusès Lietuvos architektūros palikimas, siekiant ịvardyti Lietuvos modernizmo stiliaus bruožų turinčių sovietmečio statinių būklę. Straipsnis parengtas pagal autorès magistro baigiamajjį darbą tema „Modernizmo architektūros praradimai Lietuvoje ${ }^{1 “}$.

\section{Modernizmo architektūra Lietuvoje kaip sovietmečio palikimas}

1955 m. priimtas SSKP CK ir SSRS MT nutarimas „Dèl projektavimo ir statybos nesaikingumų pašalinimo"

\footnotetext{
1 Magistro baigiamasis darbas apgintas 20080616 VGTU Architektūros pagrindų ir teorijos katedroje, vadovas doc. dr. Tomas Grunskis.
} 
(Literatūra ir menas 1955), paskelbęs naują architektūros politiką (standartizacija ir masine statyba) (Drèmaitė 2006: 32), buvo nepaprastai reikšmingas Lietuvos architektūros raidai, jis ,, atvèrè kelius funkcijos ir konstrukcijos prioritetui statyboje“ (Petrulis 2005: 6). Atsisakius puošybos, Lietuvos modernizmo architektūra estetinèmis savybèmis ir idejiniu pagrindimu priartejjo prie Vakarų modernizmo stilistinių tendencijų. Tai analogų neturintis atvejis, kai architektūros išraiška buvo veikiama valstybès politikos, siekiant statyti daug, pigiai ir greitai. Kartu tai naujos lietuviškosios architektūros mokyklos, subrandinusios pirmuosius Lietuvos modernistus, kūrusius išsivaduojant iš socialistinio realizmo ideologijos, atsiradimo metas (Petrulis 2007, Drèmaitè 2006).

Modernizmo architektūros palikimas ịvairių kritiku darbuose vertinamas ir apibrèžiamas skirtingai iš dalies dèl per mažo laiko tarpo, skiriančio praeito amžiaus socialinius reiškinius ir estetines nuostatas nuo dabarties, o, kita vertus, dèl labai prieštaringo, daugialypio okupacinių režimų pažymèto laikotarpio. Menotyrininkè Skaidra Trilupaitytè teigia, kad kone visuomet, kai kalbama apie sovietinio meno palikimą, aktualizuojamas meno ir politikos ryšys. „Viena vertus, pripažinus, kad meninis gyvenimas sovietmečiu buvo itin komplikuotas ir sąlygojamas kompromisų, jis neretai supaprastintai ivardijamas kaip oficialiajai ideologijai subordinuota realybė. Kita vertus, analizuojant konkrečius laikotarpio kūrinius, ne kartą kalbèta apie drąsią, „laisvą“, etc. meninę raišką, o ji retrospektyviai net tapatinta su politiniu pasipriešinimu priespaudai“ (Trilupaitytė 2007).

Paradoksalu, tačiau sovietmetis, būdamas nesenas laikotarpis, yra istorinès sąmonès ir akademinių interesų pakraštyje. Istorikè Rasa Čepaitienè teigia: „Marginalumo pojūtis remtųsi įspūdžiu, kad sovietinių žmonių tikrovès patirtis iš esmès buvo suskilusi. Oficialiosios galios propaguojamas diskursas palaike iškreiptą pasaulèvaizdi, orientuotą i utopijos igyvendinimą <...> galbūt nenoras juo domètis susijęs su iliuzija, kad pergyvenę sovietmetį mes jau viską apie jį žinome ir esame pajègūs teisingai vertinti?"“ (Čepaitienè 2003: 74), tačiau akivaizdu, kad mes šiuo metu bene daugiau žinome apie XV a. ir XVI a. LDK negu apie sovietinę visuomenę. Istorikès teigimu, „<...> nuo Atgimimo laikų visuomeneje paplitęs apriorinis sovietmečio atmetimas ir/ar jo subanalinimas masinëje sąmonèje turèjo įtakos sovietinès epochos materialiojo palikimo niekinimui ar net sąmoningam naikinimui. Tačiau atmetant ideologiškai „svetimą“ paveldą nejučia mažèja ir „savo“vertė“ (Čepaitienè 2003: 77). Juk tai, kad sovietinio laikotarpio reiškinių ir objektų pripažinimo paveldu klausimas dar nepradètas svarstyti visuomenëje, o sovietinè atmintis ignoruojama, rodo vis dar jautrią sąmonę patirtoms istorinèms traumoms, kuri neleidžia užmegzti dialogo su šia skaudžia ir sudètinga praeitimi, geriau ją pažinti. Tam pritartų Leonidas Ziberkas: „<...> kiekviename, net ir negatyviame laiko tarpsnyje galime rasti ir pozityvių kūrybinès veiklos rezultatų. Kultūros istorija rodo, kad dažnai geri kūrybiniai rezultatai yra pasiekiami ir nepalankiomis sąlygomis. Profesionalumas ir kūrybinès ambicijos neretai nugali ir padeda išnaudoti ar net viršyti visas sistemos galimybes" (Ziberkas 2004: 117). Akivaizdu, kad neseno laikotarpio architektūros palikimą reikètų vertinti būtent kaip kūrybinès sferos rezultatą, suprantant (o ne ignoruojant) susidariusios padèties priežastis.

Kadangi šiuo metu išsamūs sovietmečio architektūros moksliniai tyrimai neatliekami, negalima nustatyti santykinès meninès ir techninės šių objektų vertės. Tai turi įtakos pastatų išsaugojimui (ypač neišsaugojimui) ir požiūrio ị juos formavimui. Dèl tos pačios priežasties negali būti nustatoma ir objektų retumo vertè, todèl dauguma sovietmečio objektų laikomi tipiniais (apie architektūros vertes rašo Andriušyte 2007, Štelbienė 2000, Vyšniūnas 2004). Atlikus konkrečius mokslinius tyrimus, paaiškètų daugiau objektyvių tokių objektų saugojimo verčiuc.

Apibendrinant galima teigti, kad modernizmo architektūros palikimo vertinimai nèra vienareikšmiai dèl simbolinès tokių pastatų reikšmès ir jų užimamos vietos mieste. Tokiai architektūrai ideologiškai būdingas istorinių stilių ir istorijos mokymo atmetimas iškelia etini modernizmo architektūros paveldo klausimą teoriniame lygmenyje (Petrulis 2007). Praktiniame lygmenyje posovietinèse šalyse modernizmo architektūros vertinimai yra nulemti a) architektūrai primetamos politinès, ideologinès potekstès negatyvumo; b) masinès, tipinès, unifikuotos statybos padarinių - architektūra nelaikoma originalia ir autorine; c) pastatu funkcijos pasikeitimo dèl ekonominès santvarkos pokyčių ir iš to išplaukiančiu rekonstrukciju; d) ekonominès santvarkos nulemtų žemės kainų pokyčių, kurie susiję su „nepatrauklių" pastatų pasikeitimais. Tai sparčių Lietuvos modernizmo architektūros transformacijų priežastys.

\section{Sovietmečio architektūros transformacijos}

Remiantis prielaida, kad stiliaus tendencijų atitikimas gali būti laikomas vertybe ${ }^{2}$, šioje straipsnio dalyje analizuojami vertingiausi sovietmečio architektūros kū- 

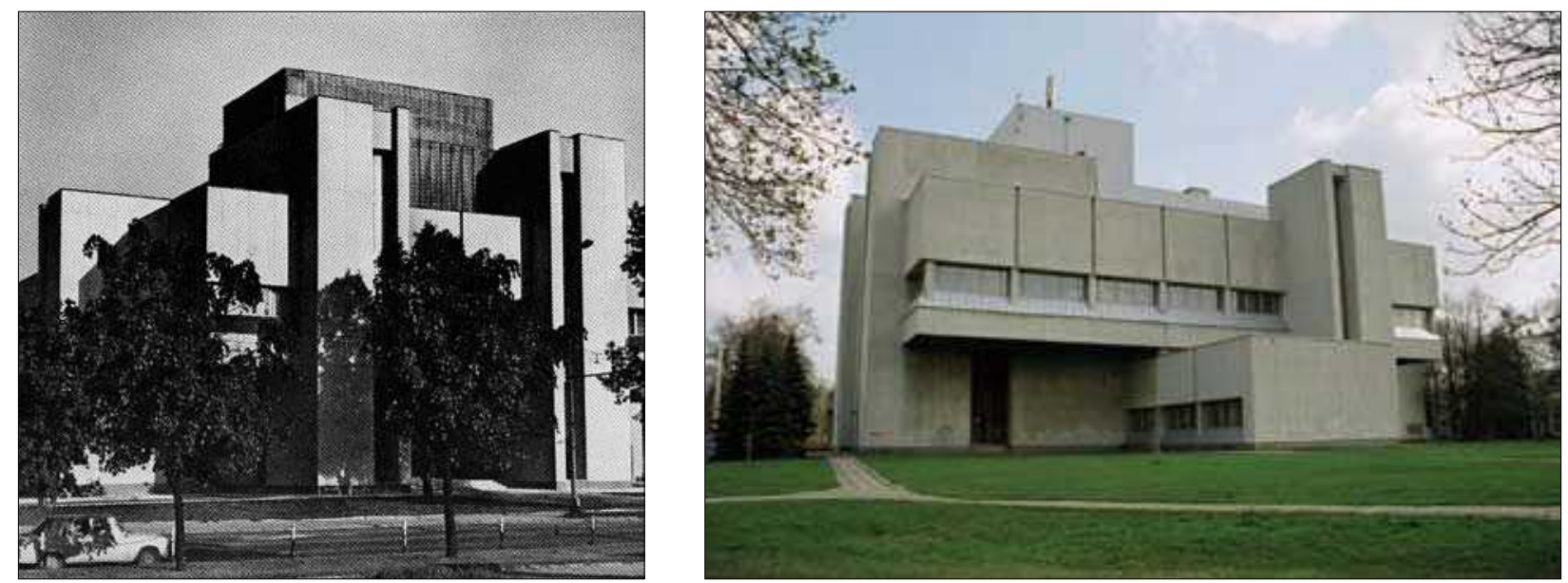

1, 2 pav. Sporto ir pramogų rūmai Vilniuje (arch. A. Mačiulis) 1983 m. ir dabar (1 pav. paimtas iš J. Minkevičius. Architecture of the soviet Lithuania. Maskva: Stroiizdat, 1987; 2 pav. nuotrauka G. Ilgūno)

Figs. 1, 2. Sports and Entertainment Palace in Vilnius (arch. A. Mačiulis) in 1983 and 2008

riniai ir išskiriami praradimai, kurie suvokiami fizine prasme - kaip objektų transformacijos, renovuojant, rekonstruojant ar kitaip keičiant pradinị pavidalą. Analizuojant Lietuvos modernizmo architektūros būklę, t. y. originalią pastatų išvaizdą lyginant su dabartine, didžiausi pokyčiai suskirstyti ị keletą grupių, apie kurias ir kalbama šiame straipsnyje. Pateikiami tik kai kurie - būdingiausi pavyzdžiai, leidžiantys padaryti išvadas apie esamą padetį. Jie turètų iliustruoti esamą Lietuvos sovietmečio modernizmo architektūros būklę ir implikuoti tolesnio elgesio su ja sprendimus, kurie liečia ne tik konkrečių pastatų paveldo sąrašus, bet ir vertingujjų savybių apsaugos ir elgesio su jomis gaires.

\subsection{Rekonstruoti arba renovuoti ir dèl to praradę kai kurias modernizmo savybes pastatai}

Šiai pastatų grupei būdinga tai, kad, renovuojant ar rekonstruojant pastatus, keičiant jų funkciją ar tik siekiant pagerinti fizinę būklę, dažnai neatsižvelgiama ị būdingiausias modernizmo architektūros savybes ir kai kurios jų prarandamos. Labai dažnas atvejis - keičiama pastatų apdaila, neatsižvelgiant $i \underset{\text { tai }}{\text { k kad neapdailintas }}$ betonas, baltas tinkas buvo esminiai modernizmo architektūros estetikos bruožai. Kitas atvejis - keičiama plano struktūra ir taip pažeidžiamas vienas svarbiausių modernizmo principu - formos ir funkcijos priklausomybė. Taip dažniausiai nutinka dèl to, kad šie objektai

\footnotetext{
2 Toks vertès suvokimas leistų pastatus, turinčius modernizmo architektūros bruožu, laikyti neatsiejama architektūros istorijos dalimi, ir tai suteiktų jiems papildomų išsaugojimo ir eksponavimo galimybiu.
}

neįtraukti į paveldo sąrašus, nèra saugotinų vertingiausių modernizmo savybių sąrašo arba konkretaus pastato saugotinų vertybių sąvado.

Šiuos pastatus sąlygiškai galima suskirstyti i grupes: - rekonstruotas pastato vidus (keičiant funkciją pažeistas pastato tūris);

- rekonstruota architektūrinè išraiška (keičiant apdailą prarandamos modernizmo savybès);

- rekonstruota ir funkcija, ir architektūrinè išraiška.

A. Mačiulio suprojektuoti pramogų ir sporto rūmai Žirmūnuose (1, 2 pav.) - rusiškojo konstruktyvizmo paveiktas kūrinys. Jam būdinga ekspresyvi tūrių kompozicija atliekant remontą buvo sunaikinta. Nors pastato funkcija iš esmès nepakito, tačiau, keičiant susidèvejjusią apdailą, nepaisyta modernistinių pastato savybių. Pakeitus tamsaus medžio apdailą šviesia skarda, suardyta pastato tūrinè kompozicija, prarastas ryškus „apatinès“ ir „viršutinès“ dalies kontrastas. Nors iš esmès tūriniai sprendimai neliesti, tačiau pastatas vizualiai pakito.

Priešingas, bet taip pat dažnas rekonstrukcijos pavyzdys Vakaruose vadinamas fasadizmu, kai, paliekant vienintelį reprezentacinị (vizualiai patrauklų, tačiau nebūtinai saugomą) pastato fasadą, likusios jo dalys ir savybès negrị̌tamai pakeičiamos. Dažnos diskusijos, ar užtenka išsaugoti pastato fasadą, norint būti sąžiningais architektūros istorijos ir autentiškumo atžvilgiu. $2001 \mathrm{~m}$. atliekant rekonstrukciją, vertingas kino teatro „Vilnius“ Vilniuje (3, 4 pav.) interjeras neišliko. Taip nutiko ir su daugeliu kitu praeito šimtmečio pavyzdžių - iš visą Gedimino prospektą puošusių daugybės modernistinių interjerų paveldo statusą turi tik „Neringos" restoranas. 

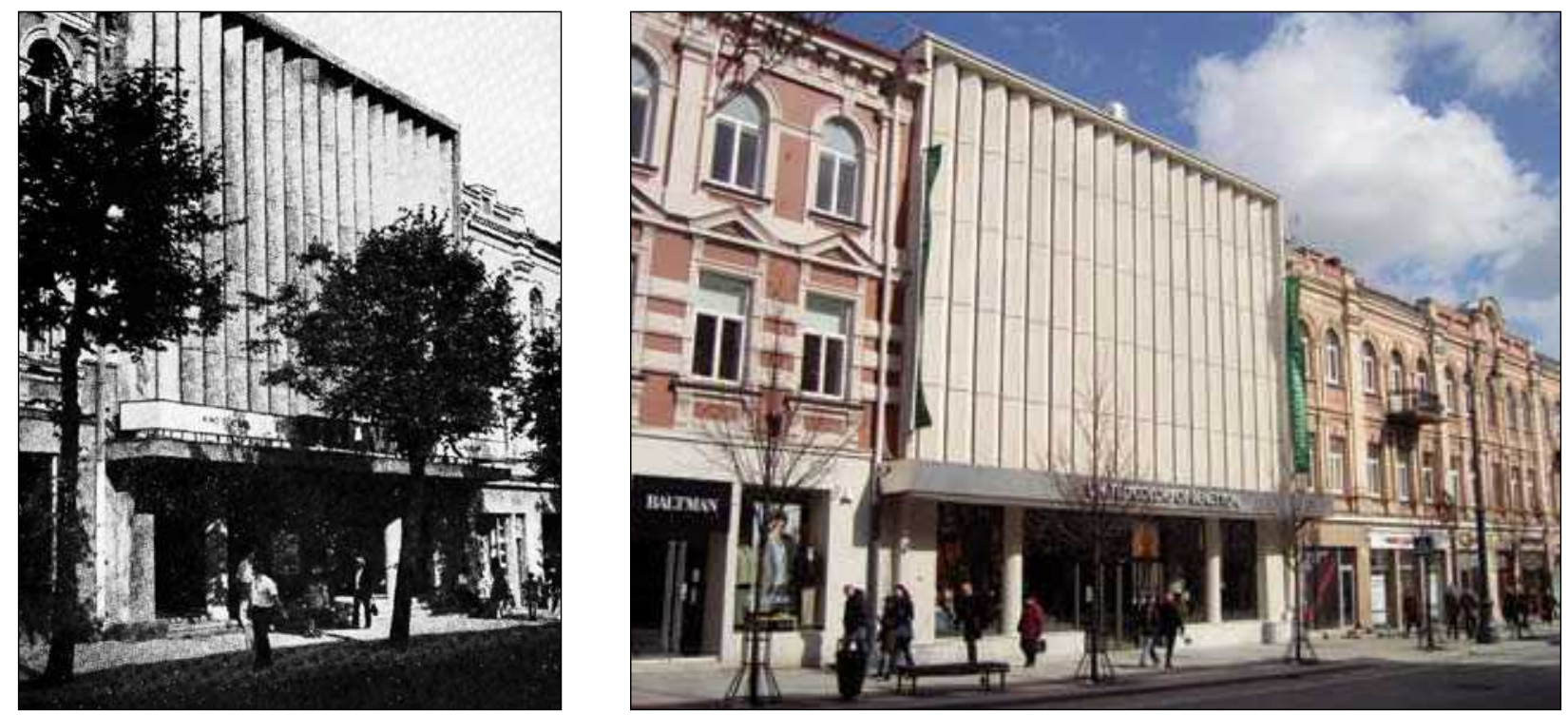

3, 4 pav. Kino teatras „Vilnius“ Vilniuje (arch. J. Kasperavičius, C. Strimaitis) 1963 m. ir dabar (3 pav. paimtas iš J. Minkevičius. Architecture of the soviet Lithuania. Maskva: Stroiizdat, 1987; 4 pav. nuotrauka G. Ilgūno)

Figs. 3, 4. Cinema "Vilnius" in Vilnius (arch. J. Kasperavičius, C. Strimaitis) in 1963 and 2008
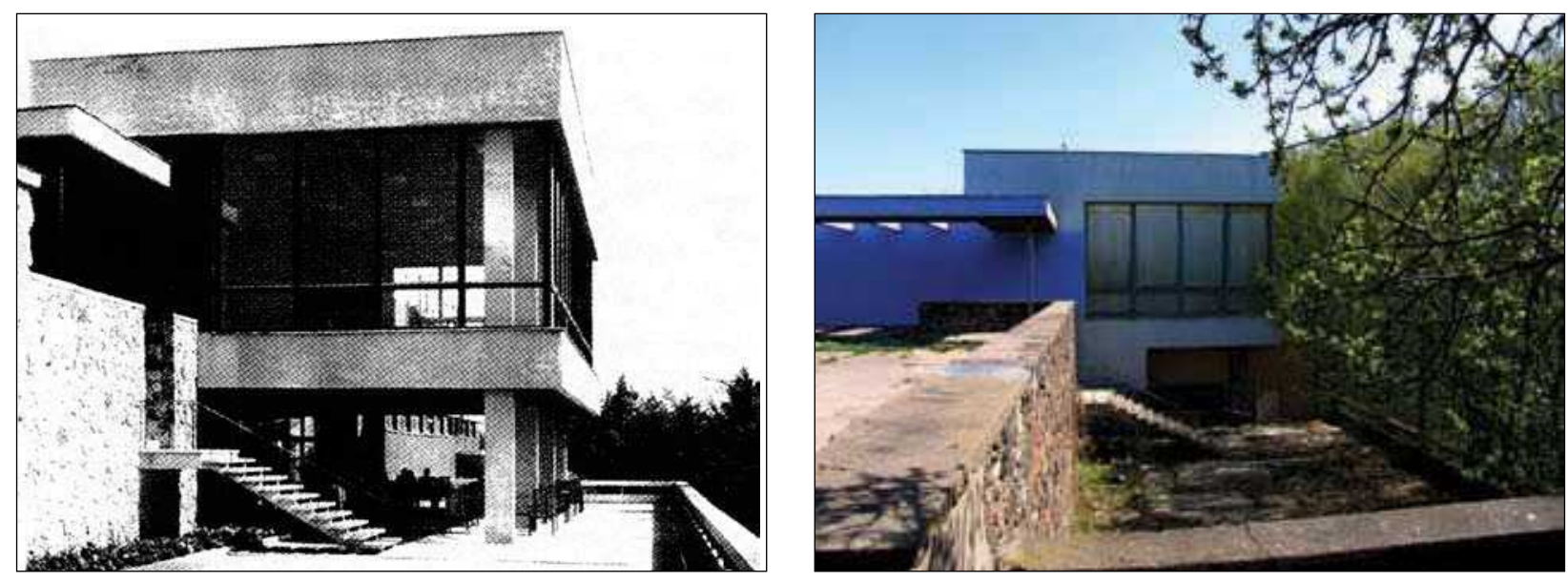

5, 6 pav. Kavinè „Trys mergelès" Kaune (arch. A. and V. Jakučiūnai) 1967 m. ir dabar (5 pav. paimtas iš Lietuvos architektai/ LAS. Vilnius: Lietuvos dailès akademijos leidykla, 2000; 6 pav. nuotrauka autorès)

Figs. 5, 6. Cafe "Trys mergelès" in Kaunas (arch. A. and V. Jakučiūnai) in 1967 and 2008

„Trijų mergelių“ kavinè Kaune (5, 6 pav.) laikoma vienu stilingiausių sovietinio laikotarpio architektūros pavyzdžių. Ištęstas pastato siluetas su virš upès kabančiu tūriu, stiprus ir organiškas interjero ryšys su gamta yra didžiausia kavinès autorių sèkmè. Šiandien „Trys mergelès" rekonstruojamos, keičiamas interjeras. Visus langus aklinai uždengė gipso konstrukcijos. Pertinkuojant fasadą suardytas ankstesnis horizontalus jo skaidymas. Šiuo metu pastatas apleistas. Ryškiai violetiniai fasadai jo nepuošia.
2003 m. vykdyta viešbučio „Turistas“ (7, 8 pav.) Vilniuje renovacija atlikta nepaisant modernistinių pastato savybių, architektūrinè pastato išraiška pakeista negrịžtamai. Nors tūris iš esmès neliestas, naujomis apdailos medžiagomis sunaikintas jo kompleksiškumas. Dabar pastatas disonuoja su aplinkiniu užstatymu. Viso modernistinio kvartalo ateitis šiuo metu neaiški, galibūti, kad, sparčiai vykstant dešiniojo Neries kranto plètrai, viso komplekso išraiška bus radikaliai pakeista. 

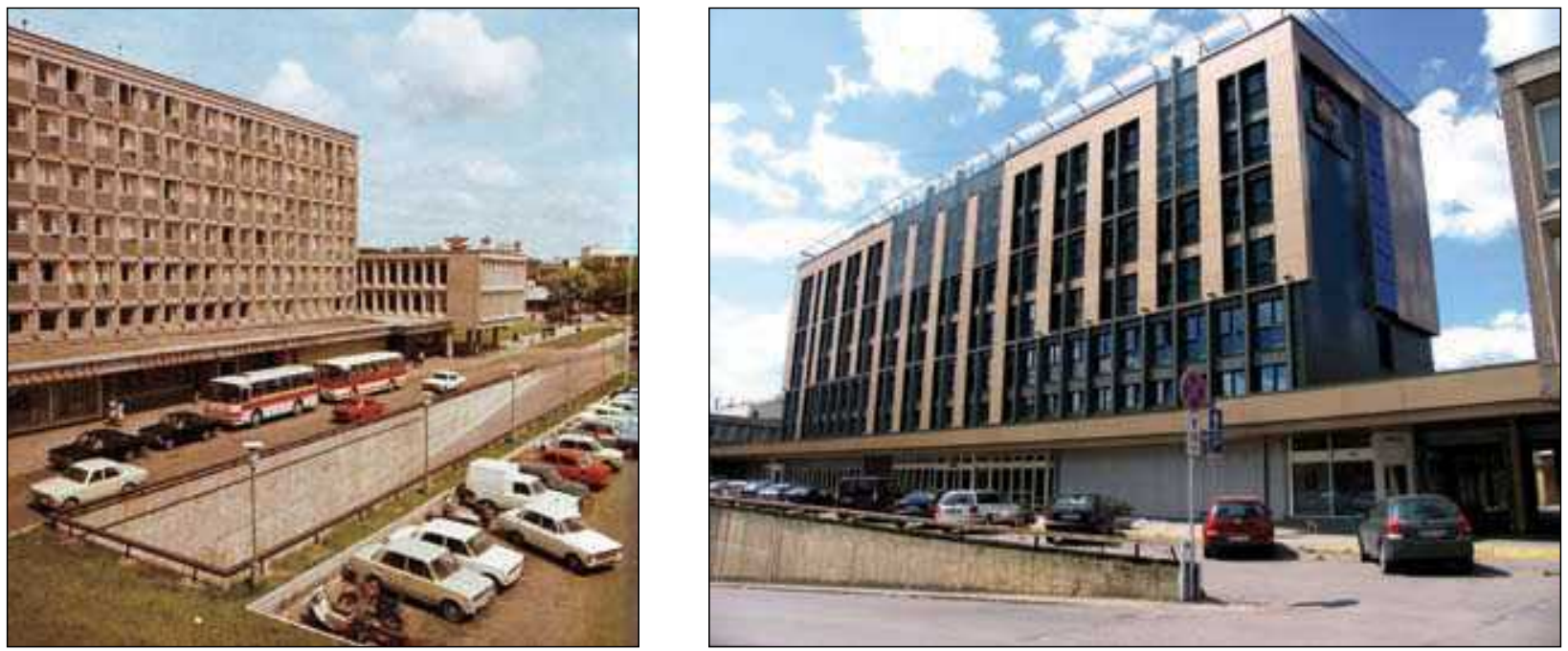

7, 8 pav. Viešbutis „Turistas“ Vilniuje (arch. J. Šeibokas) 1978 m. ir dabar (7 pav. paimtas iš katalogo Vilnius. Vilnius: Mintis, 1980; 8 pav. nuotrauka autorès)

Figs. 7, 8. Hotel "Turistas" in Vilnius (arch. J. Šeibokas) in 1978 and 2008
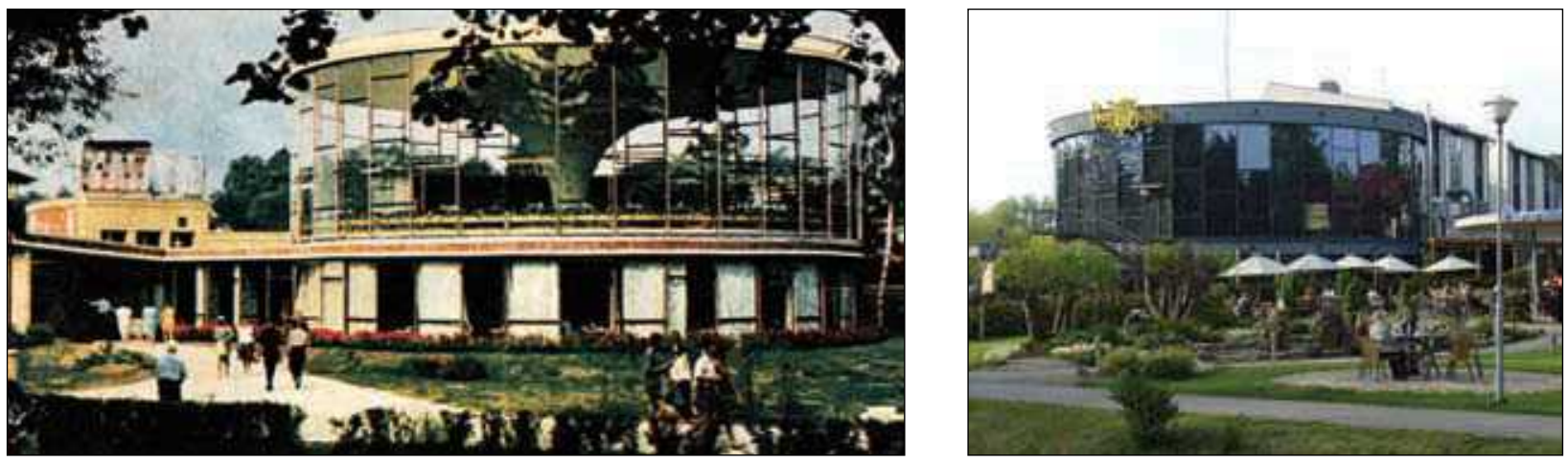

9, 10 pav. Restoranas „Vasara“ Palangoje (arch. A. Eigirdas) 1964 m. ir dabar (9 pav. paimtas iš Švyturys, 1966 m. gegužės 9 d.; 10 pav. nuotrauka A. Gabrèno)

Figs. 9, 10. Restaurant "Vasara" in Palanga (arch. A. Eigirdas) in $1964 \mathrm{~m}$. and nowadays

\subsection{Rekonstruoti ir negrižtamai pakeisti pavyzdžiai}

Tai pastatai, kurie, nepaisant jų vertės, visuomenès požiūrio ar paveldosauginio statuso, buvo rekonstruoti pakeičiant jų esmines tiek vidaus, tiek išorines savybes. Tokie statiniai dažnai sékmingai buvo pritaikyti šiandienos poreikiams, tačiau jų architektūra, keičiant tūrių kompoziciją, funkcines schemas ir apdailos medžiagas, yra negrįž̌tamai pakeista. Šie pastatai dèl pernelyg didelių pakeitimų ir unikalias savybes praradę nebegali būti laikomi Lietuvos modernizmo architektūros pavyzdžiais.

1964 m. statytas restoranas „Vasara“ Palangoje (9, 10 pav.) išsiskyrèitin originalia konstrukcija ir modernistine išraiška. $2003 \mathrm{~m}$. pastatas rekonstruotas praplečiant bendrą jo plotą ir pakeičiant apdailos medžiagas. Taip skaidrus apskritas tūris tapo nepermatomu būgnu, sunaikinta originali pirminè jo išraiška. Tai vienas iš atvejų, kai neatsargiai elgiantis su architektūra gaunama nauja kokybė, tačiau stiliaus savybès yra negrižtamai pakeičiamos. Pastatą galima laikyti vienu didžiausių Lietuvos plastiškojo modernizmo architektūros praradimų.

„Miestprojekto“ rūmų Kaune (11, 12 pav.) rekonstrukcija susilaukè visuomenès ir profesinès bendruomenès pasipriešinimo, vis delto negrižžtami pakeitimai vienu geriausių laikomam Lietuvos funkcionalizmo pavyzdžiui buvo padaryti. Galutinè pastato rekonstrukcija nèra tokia drastiška kaip konkursą laimejję pavyzdžiai, tačiau pagrindinè modernistinè šio pastato savybè - fasadai buvo rekonstruoti. Pastato išsaugoti nepadejo nei jo autoriui Antanui Sprindžiui suteiktas Architektūros 

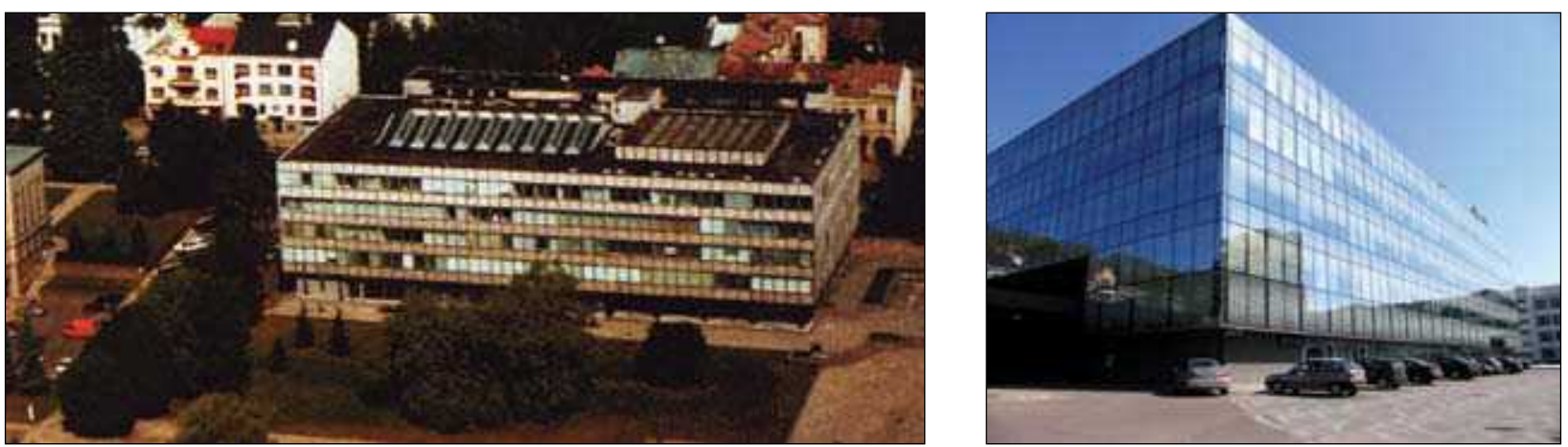

11, 12 pav. „Miestprojekto” rūmai Kaune (arch. A. Sprindys) 1972 m. ir dabar (11 pav. paimtas iš Statybu pilotas, 200305 16; 12 pav. nuotrauka autorès)

Figs. 11, 12. "Pramprojektas" in Kaunas (arch. A. Sprindys) in 1972 and nowadays

riterio vardas, nei Architektų sąjungos pareiškimai. Šis atvejis gali būti laikomas vienu skaudžiausių modernizmo architektūros praradimų Kaune.

Buvusi originali baldų parduotuvès „Klevas“ $\mathrm{Pa}$ nevèžyje (13, 14 pav.) apdaila - iš išorès „pakabintas“ iš betono išlietas ažūras - asketiška modernistinè detalè, kubo formos pastatui suteikianti lengvumo, žaismingumo, - yra negrižtamai sugadinta rekonstrukcijos metu. Pastato tūris sudarkytas keičiant apdailą. Tai pavyzdys, kaip neatsargus elgesys su atskiromis praejusio amžiaus architektūros detalèmis gali radikaliai pakeisti architektūrinę išraišką.
N. Bučiūtės suprojektuota baldų parduotuvė Vilniuje $(15,16$ pav.) buvo laikoma vienu iš sèkmingiausių Lietuvoje paviljoninès architektūros pavyzdžių stambus geometrinès išraiškos tūris su ịspūdingai atvira vidine erdve buvo to meto Lietuvos funkcionalizmo ir techniniu galimybių demonstravimo etalonas. 1990 m., vykdant rekonstrukciją, pakeista ne tik pastato funkcija, suniveliuota stogą laikanti erdvinè santvara ir ,prigesinta“ bendra atvira erdvè, bet ir išorès apdailai pasirinkta skarda, kuri pakeičia pastato masteli, suskaido monumentalų tūrị ir išbraukia ji iš modernizmo architektūros pavyzdžių sąrašo.
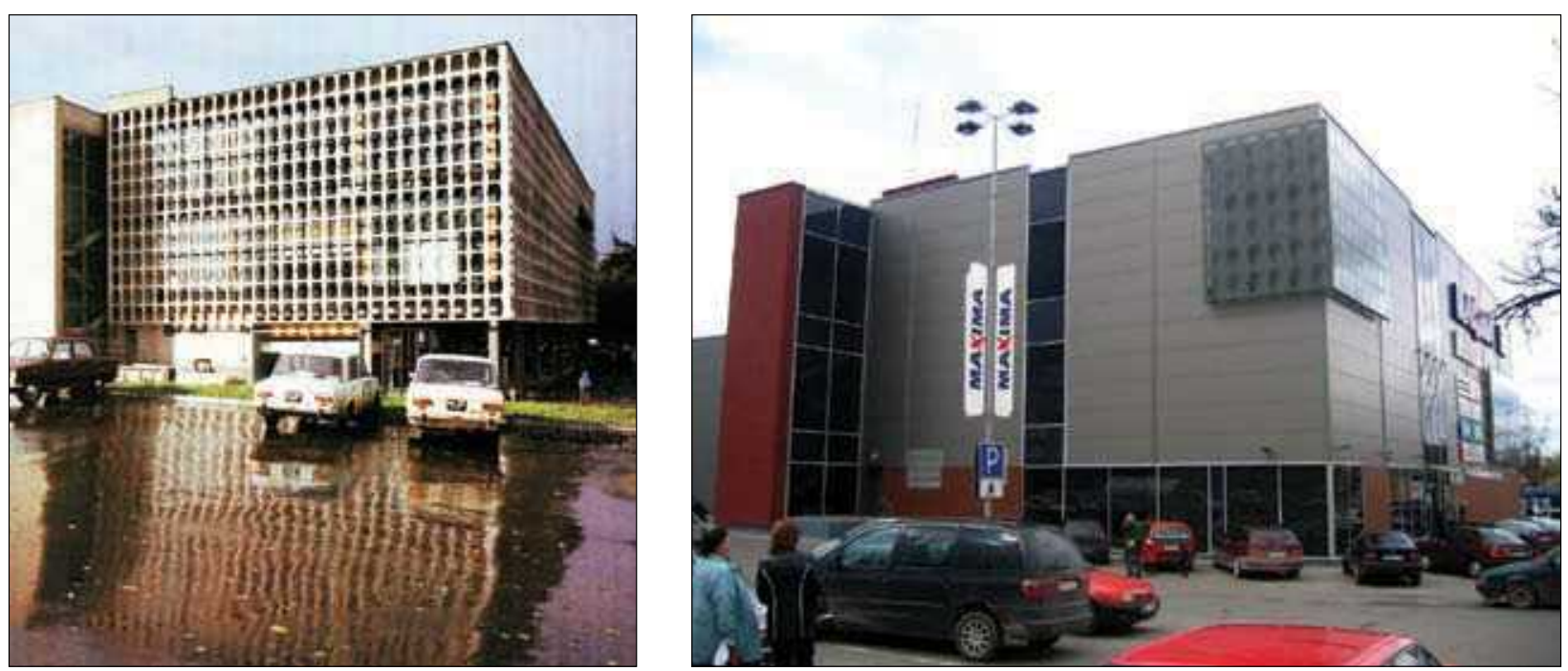

13, 14 pav. Baldų parduotuvė „Klevas“ Panevėžyje (arch. N. Grabliauskienè) 1970 m. ir dabar (13 pav. paimtas iš L. Skrebė. Panevėžys. Vilnius: Mintis, 1984; 14 pav. nuotrauka I. Račkausko)

Figs. 13, 14. Furniture Store "Klevas" in Panevėžys (arch. N. Grabliauskienė) in 1970 and 2008 

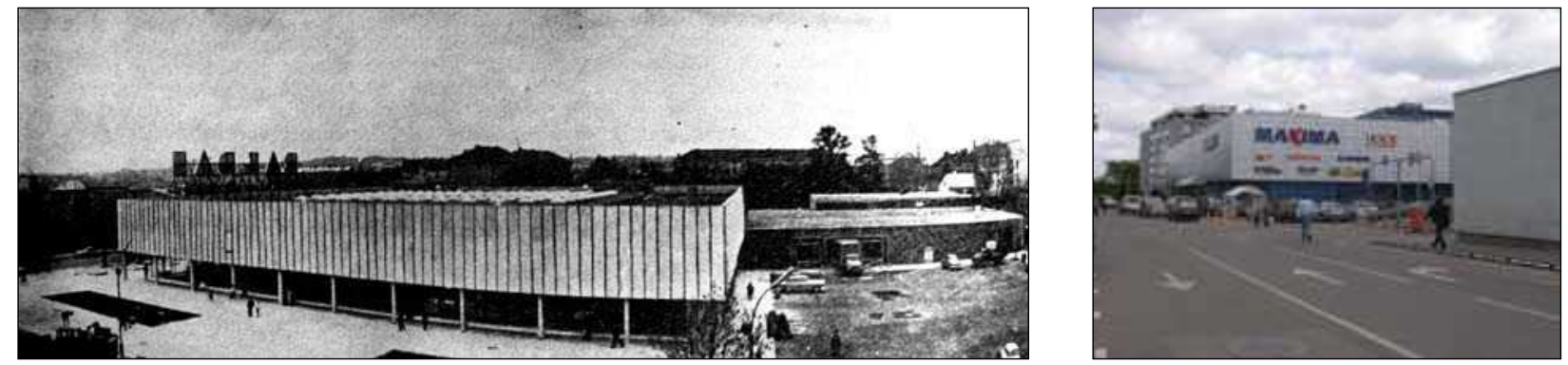

15, 16 pav. Baldụ parduotuvès paviljono pastatas Vilniuje (arch. E. N. Bučiūtè) 1974 m.; rekonstruotas 1990 m. (15 pav. paimtas iš Statyba ir architektūra, 1968/6; 16 pav. nuotrauka autorès)

Figs. 15, 16. Furniture Store Pavilion in Vilnius (arch. E. N. Bučiūtè) in 1974 reconstructed in 1990

\subsection{Esantys pavojuje - neturintys reikiamo statuso ir nesaugomi pastatai}

Šie objektai, laiku nesulaukę reikiamo paveldosaugininku dèmesio, neįtraukti ị paveldo sąrašus, todèl dažnu atveju yra privatizuoti. Jų likimą sprendžia savininkai dažnai ne modernizmo architektūros naudai. Dabartinè tokių pastatų situacija yra neapibrèžta, jie dar nerekonstruoti, nerenovuoti, tačiau dažniausiai tai laiko klausimas, juolab, kad nenaudojami tokie pastatai griūva, o jų savininkai nèra suinteresuoti jų architektūrinès išraiškos išlikimu.

„Tauro ragas“ (17 pav.), suprojektuotas ir statytas laikinam naudojimui, buvo didžiausias alaus restoranas Sovietų Sajungoje. Pagrindinè šio objekto problema mastelis: statant buvo nepaisoma aplinkinio užstatymo ir greta esančios sankryžos, kas dabar tampa pagrindiniu argumentu siekiant pastatą nugriauti. „Baigiami rengti naujo pastato projekto pasiūlymai. „Tauro ragas“ neišvengiamai bus nušluotas nuo žemés paviršiaus", - rašoma 2007 m. žurnale „Statyba ir architektūra“ (Nemeikaite 2007: 57). Vilniuje neliks dar vieno modernistinès architektūros ženklo, nors, specialistų teigimu, tai ne tik stilingas, bet ir būdingas brutalizmo architektūros pavyzdys, turintis itin retų ir saugotinų savybių.

"Merkurijus" - Kauno Laisvès alèjos simbolis (18 pav.). Pagrindinè problema ir būsimos radikalios rekonstrukcijos priežastis - pastato tūris, esant didelių prekybos centrų poreikiui, pernelyg mažas ir nebeatitinka pakitusių funkcinių poreikių. Argumentas, kad pastatas negražus, yra kritikuojamas architektūrinès visuomenès, tačiau šio objekto likimą nulèmè tai, kad jis nebuvo laiku ịrašytas ị paveldo registrą, nę̨vardytos vertingosios jo savybès. Kauno miesto savivaldybè jau pritare šio pastato praplètimui iki $17000 \mathrm{kv}$. m, jo fasadu keitimui ir visiškai rekonstrukcijai.

Panašioje situacijoje atsidūrè J. Šeiboko suprojektuotas originalus Ryšių ministerijos pastatų

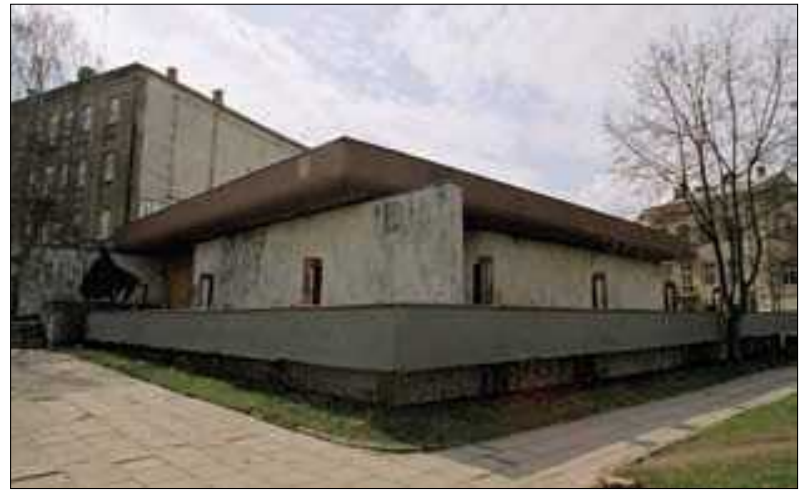

17 pav. Alaus restoranas „Tauro ragas“, (arch. E. Gūzas, A. Mačiulis) 1974 m. (nuotrauka G. Ilgūno)

Fig. 17. Beer Restaurant "Tauro ragas"

(arch. E. Gūzas, A. Mačiulis) built in 1974

kompleksas (19 pav.). Kadangi jis neatitinka funkcinių komplekso reikalavimu, esant gan prastai statybos darbų kokybei, buvo pasirinktas paprasčiausias variantas kompleksą nugriauti, nepaisant jo unikalumo ir originalių architektūrinių, modernizmui būdingų savybiu, ir vystyti naują užstatymą.

$2002 \mathrm{~m}$. privatizuotas kino teatras „Lietuva“ (20 pav.) Vilniuje svarbus ne tik kaip architektūros objektas, bet ir kaip vieša kultūrinė erdvè. Jau pakeitusio ne vieną savininką pastato griovimo darbai iki šiol nepradèti visuomenei pasipriešinus. Susidariusi situacija iliustruoja viešos diskusijos nebuvimo pasekmes. Projektuojant kino teatro vietoje daugiabuti gyvenamaji namą nepaisoma to, jog pastatas stovi senamiesčio apsaugos zonoje ir jokie tūriniai pakeitimai čia neturetų būti vykdomi. Objektas neturi jokio apsaugos statuso, yra kritikuojamas kaip „betoninis monstras” ir „tipinis sovietmečio projektas". Tai rodo, kokia svarbi pastato likimui gali būti apie jị formuojama nuomonè. 


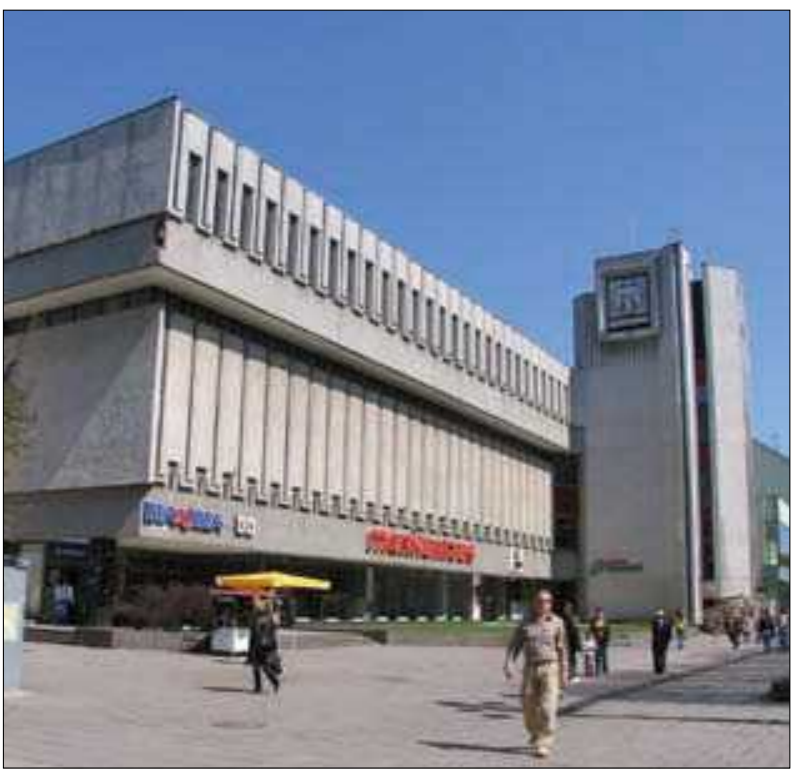

18 pav. Parduotuvè "Merkurijus" Kaune (arch. A. Sprindys) 1982 m. (nuotrauka autorès)

Fig. 18. Commissary "Merkurijus" in Kaunas (arch. A. Sprindys) built in 1982

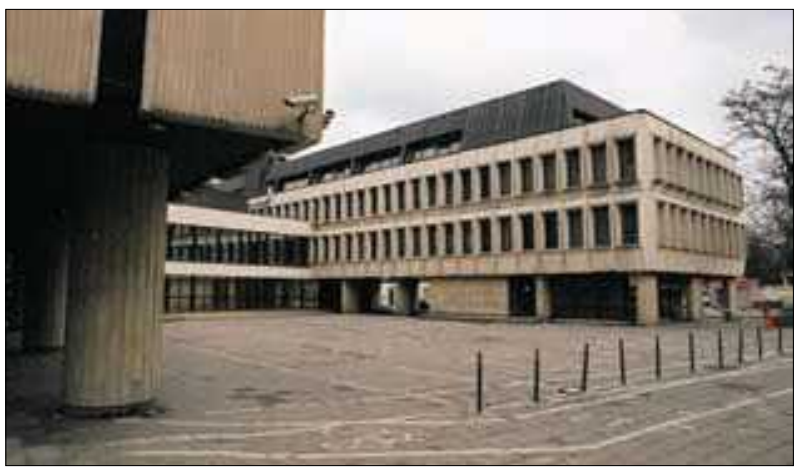

19 pav. Ryšių ministerijos objektų kompleksas (arch. J. Šeibokas) 1978-1979 m. (nuotrauka G. Ilgūno) Fig. 19. Communication Complex in Vilnius built in 1978-1979

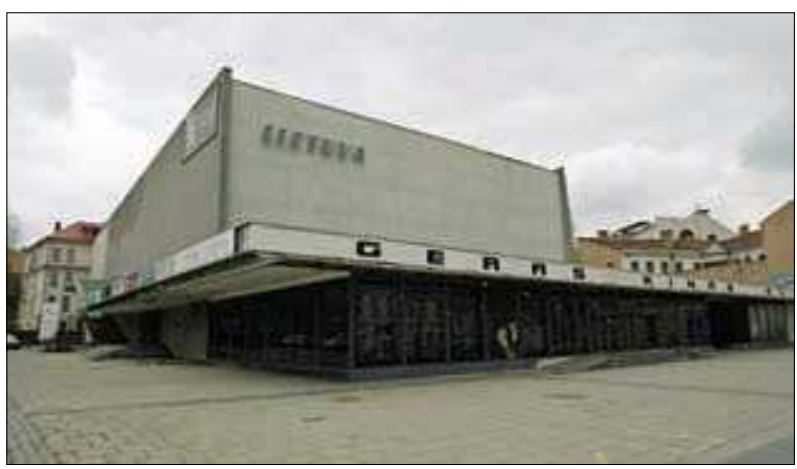

20 pav. Kino teatras „Lietuva“ Vilniuje (arch. J. Kasperavičius) 1959-1965 m. (nuotrauka G. Ilgūno)

Fig. 20. Cinema "Lietuva" in Vilnius (arch. J. Kasperavičius) built in 1959-1965

\subsection{Paveldo statusą turintys pastatai, kurių situacija neapibrèžta}

Tai pastatai, kuriems suteiktas kultūros vertybès statusas, tačiau, nepaisant to, jų likimas vis tiek nèra aiškus.

2006 m. Kultūros paveldo departamento Nekilnojamojo kultūros paveldo vertinimo taryba Vilniaus koncertų ir sporto rūmus įrašè ị Kultūros vertybių registrą. Pastatą siūloma saugoti regioninès reikšmès lygmeniu. Tačiau objektas dar nèra ministro įsakymu paskelbtas saugomu.

Unikalios architektūros koncertų ir sporto rūmų (21 pav.) konstrukcijos pripažintos pasauliniu atradimu. Pastatas patenka ị archeologijos kultūros vertybès Vilniaus senojo miesto vietos su priemiesčiais teritoriją. $1988 \mathrm{~m}$. spalio 22-23 d. Vilniaus koncertų ir sporto rūmuose įvyko Lietuvos Persitvarkymo Sajūdžio steigiamasis suvažiavimas. $1991 \mathrm{~m}$. sausio 14-16 d. visuomene atsisveikino su pastate pašarvotais Lietuvos laisvès kovotojais, žuvusiais prie Vilniaus televizijos bokšto, kas rodo memorialinę šio pastato vertę (kuri, deja, dažniau nei architektūrinès savybès lemia architektūros likimą). Pastato ateitis neaiški. Savivaldybė žada Sporto rūmus išpirkti, tačiau delsia tai padaryti. $2008 \mathrm{~m}$. kovo mèn. savininkų pastangomis įvyko „Teritorijos tarp Neries upes, Rinktinès, Šeimyniškių ir Raitininkų gatvių, Vilniuje, projekto urbanistiniųarchitektūrinių pasiūlymų konkursas."

Jei praradimais laikytume jau įvykdytus (nę̨traukiant planuojamų) destruktyvius veiksmus minètosios architektūros atžvilgiu, tai per nepriklausomybès laikotarpị iš 65 analizuotų objektų 26 yra rekonstruoti, renovuoti ar kitaip pakeisti. Iš jų 12 atvejų pakeista pastatų kompozicija, 14 - plano struktūra, 22 pastatų atlikti fasadų apdailos pakitimai, iš jų net 20 atvejų pakeistas pradinis koloritas ir 18 - originalios detalès, 13 nagrinètų objektų yra praradę pirminị transparentiškumą. Lyginant pakitusių objektų pradinę ir esamą būklę pagal vienodus modernizmo architektūros bruožus, paaiškèjo, kad iš visų šių 65 pastatų 52 atvejais yra pakitę architektūros kompoziciniai bruožai, 22 - plano struktūros bruožai, 37 - apdailos, 24 - konstrukcijos ir 21 - detalių bruožai. Tai tik nedidelè ir gana subjektyvi tyrimo dalis, tačiau ji iliustruoja sparčius ne tik kokybinius, bet ir kiekybinius Lietuvos modernizmo architektūros pokyčius, kas verčia nerimauti dèl netolimos tokių objektų ateities. 


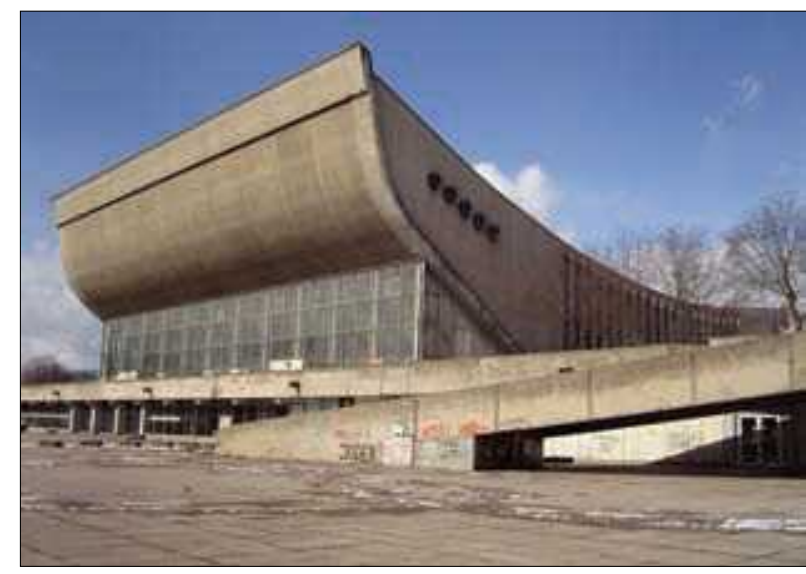

21 pav. Vilniaus koncertụ ir sporto rūmai

(arch. E. Chlomauskas, J. Kriukelis, Z. Liandzbergis) 1971 m. (nuotrauka G. Ilgūno)

Fig. 21. Palace of Sports and Culture in Vilnius (arch. E. Chlomauskas, J. Kriukelis, Z. Liandzbergis) built in 1971

\section{Apibendrinimai}

1.Lietuvoje yra originalių ir savitų modernizmo architektūros savybėmis pasižyminčių pastatų, kurie nevertinami nyksta. Modernizmo architektūrai būdingas istorinių stiliu ir istorijos mokymo atmetimas ir nevienareikšmis požiūris i neseno okupacinio periodo palikimą lemia neigiamas visuomenès nuostatas ir tokios architektūros paveldosaugos gairių nebuvimą. XX a. architektūros būklè yra glaudžiai susijusi su sociopolitinès situacijos pakitimais. Sovietmečiu daugiausia buvo statoma modernistinėmis savybėmis išsiskiriančiu visuomeninès paskirties pastatų, kurie, pasikeitus ekonominei santvarkai, privatizuojami arba tampa nenaudojamais. Viso to rezultatas - pasikeitusi architektūrinè išraiška ir prarandamos stiliaus savybès. Modernizmo architektūros funkcijos tęstinumas leistų suteikti tokiems statiniams papildomos ekonominès bei socialinès vertès ir padètų išsaugoti vizualines modernizmui būdingas savybes.

2.Specialiu modernizmo architektūros vertinimo gairių, priežiūros priemonių ar nuostatų Lietuvoje nèra. Lietuvos dauguma sovietmečio architektūros pavyzdžių dèl konversijų ir renovacijų praranda modernizmo architektūrai būdingas savybes tiek tūrio, tiek plano struktūros, tiek apdailos lygmenyje. Yra negrị̌ztamai pakeistų ir visiškai praradusių modernizmo architektūros bruožus pastatų, kurie nebegali būti laikomi modernizmo architektūros pavyzdžiais.

3. Kiekybiniai Lietuvos modernizmo architektūros bruožų pokyčiai verčia nerimauti, kad tam tikro istorinio laikotarpio pavyzdžiai gali išnykti iš miesto architektūros paletès. Empirinè dabartinès modernizmo architektūros būklès apžvalga rodo, kad beveik 50 proc. analizuotų pastatų yra rekonstruoti, renovuoti ar kitaip praradę pradini pavidalą. Dažniausiai prarandami kompoziciniai šios architektūros bruožai, gausu plano struktūros, apdailos ir modernizmo architektūrai būdingų detalių pakitimų.

4.1940-1990 m. laikotarpio architektūros dabartinei situacijai įtakos turi tai, kad nèra nuodugniu mokslinių tyrimų, be kurių negalima nustatyti santykinès meninès ir techninès šių objektų vertès, negali būti nustatoma jų retumo ir unikalumo vertè. Kalbant apie tokios architektūros palikimą, būtina suvokti, kad jos autentiškumas ir originalumas yra savybès, kurios kuria pridètinę vertę, todèl XX amžiaus Lietuvos architektūrą reprezentuojančius pavyzdžius būtina fiksuoti ir saugoti.

\section{Literatūra}

Andriušytè, A. 2007. Savitumas kaip vertybė architektūroje, Urbanistika ir architektūra 31(1): 62-66.

Buivydas, R. 2001. Žvilgsnis ị XX a. architektūros pasaulị kaip ị priešpriešų istoriją, Urbanistika ir architektūra 25(2): 89-96.

Buivydas, R. 2003. Naujieji meninio vaizdo ženklinimai XX a. architektūroje, iš Architektūros kompozicijos tyrimai: mokslinių straipsnių rinkinys: 45-59.

Čepaitienè, R. 2003. Sovietmetis Lietuvos kultūros šviesoje: projekto bandymas, Menotyra 31(2): 74-80 [interaktyvus] [žiūrèta, 200805 21]. Prieiga per internetą: <http://images. katalogas.lt/maleidykla/men32/M-74.pdf $>$.

Drèmaite, M. 2006. Vytautas Edmundas Čekanauskas romantiškos sielos modernistas, portretas, Archiforma 4: 32-39.

Nemeikaitè, S. 2007. „Tauro ragas“. Tikrovè ir mitai. Populiarus alaus restoranas paneigè laikinumą ir tapo laikmečio simboliu, Statyba ir architektūra 8: 56-60.

Petrulis, V. 2005. Nacionalinio savitumo strategijos sovietmečio Lietuvos architektūroje, Urbanistika ir architektūra 29(1): 3-12.

Petrulis, V. 2007. Sovietmečio palikimas kaip etinis imperatyvas šiuolaikinei Lietuvos architektūrai, Urbanistika ir architektūra 31(1): 43-49.

Petrulis, V. 2006. Stilistinès sovietmečio architektūros vertinimo prielaidos, Urbanistika ir architektūra 30(3): 134-141.

Štelbienè, A. 2000. Apie tradicinès ir šiuolaikinès architektūros verčių lygmenis, Urbanistika ir architektūra 24(3): 97-106.

Trulupaityte, S. 2007. Totalitarizmas ir sovietinio meno vertinimo problemos posovietineje Lietuvoje, Šiaurès Atènai 12/01 (871). Parengta pagal pranešimą, $2007 \mathrm{~m}$. rugsejo $28 \mathrm{~d}$. skaitytą Taline tarptautinejje konferencijoje „Differerent modernisms, different avant-gardes“ [interaktyvus] [žiūrèta 200805 30]. Prieiga per 
internetą: $<$ http://www.culture. $>$.lt/satenai/?leid_ id $=871 \&$ kas=straipsnis\&st_id $=15597>$.

TSKP Centro Komiteto ir TSRS Ministru Tarybos nutarimas „Dèl projektavimo ir statybos nesaikingumų pašalinimo“. Literatūra ir menas. 19551112.

Vyšniūnas, J. 2004. Vizualinio identiteto apsaugos rinkos salygomis metodines nuostatos. Vilniaus miesto vizualinio identiteto apsauga ir pletros principai. Vilnius: Technika.

Ziberkas, L. P. 2004. Šeškinès visuomeninis prekybos centras: tarp praeities ir ateities, Urbanistika ir architektūra 27(3): $117-122$.

\section{LOSSES OF THE SOVIET PERIOD MODERNISTIC ARCHITECTURE IN LITHUANIA}

\section{J. Kšivickaitè}

Abstract. The paper analyses the heritage of the Lithuanian architecture of the soviet period. It is stated that there is a certain amount of buildings with modernistic features in Lithuania which are unvalued and vanishing. Pecularities of the 20th century architecture are discussed in the work as well as complicated attitude to the heritage of the Lithuanian modernistic architecture and reasons of current situation. Comparing the former and present state of the Lithuanian modernistic architecture, the biggest transformations of its most peculiar buildings are described. A conclusion is drawn that a number of the 20 th century Lithuanian buildings are vanishing and should be acknowledged and preserved as historic architectural heritage.

Keywords: soviet period, modernism, architectural heritage, transformations, losses.

\section{JULIJA KŠIVICKAITE்}

Master, doctoral student (2008), Dept of Fundamentals and Theory of Architecture, Vilnius Gediminas Technical University (VGTU), Pylimo g. 26/Traku g. 1, LT-01132 Vilnius, Lithuania. E-mail: julija.ksivickaite@gmail.com, cell: +37060099690.

Master of Architecture, VGTU, 1997. Bachelor of Architecture, VGTU, 2005. Publications: author and co-author of some architectural projects, national and international idea contests of architecture and urban design. The bursar of Socrates/Erasmus exchange programme in Vitus Bering center for higher education, Denmark and Leonardo Da Vinci programme in Rome. Collaborative projects with artists Nomeda and Gediminas Urbonas in the projects of Biennale of Venice, Moscow biennale, biennale of Lyon, as the architect of exhibitions. Research interests: interdisciplinary projects, participatory architecture, soviet period heritage, modernistic architecture. 